\section{Søvnens kulturhistorie}

\section{Pedersen MV}

I søvnens favn

Om søvn og sovevaner på landet 1600-1850.

206 s, ill. København: Museum Tusculanums Forlag, 2009. Pris DKK 248

ISBN 978-87-635-2599-2

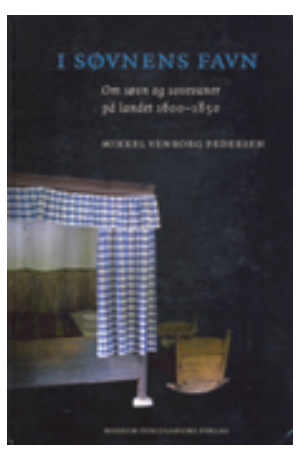

Hvordan sover vi, hvor sover vi, hva har vi over og under oss, hvordan ser sengene ut og i hvilke omgivelser står de? Søvn er ikke bare en fysiologisk prosess, den er også betinget av kulturelle forhold, som er historisk foranderlige.

I søvnens favn er en søvnens kulturhistorie fra perioden 1600-1850. Mikkel Venborg Pedersen er etnolog og arbeider ved Frilandsmuseet, som er Danmarks største museum for byggeskikk og kulturlandskap. Boken er derfor naturlig nok preget av materiale fra utvalgte gårder på dette museet. Her er vakre bilder av senger fra forskjellige sosiale lag av befolkningen, f.eks. den sjællandske festegård fra Prebringe fra slutten av 1700-tallet, fra den nesten samtidige stasgården Lundager på Fyn, og århusgården fra True fra rundt 1830. Annet kapittel om «Hos Rasmus, Anne og andet godtfolk» tar utgangspunkt i disse tre gårdene, mens de følgende kapitlene «I Halm, uld og fjer» og «Søvn og sovevaner» også bygger på andre av museets bestanddeler. Siste kapittel, «Hvilke tider, hvilke skikke!», handler om den siste del av perioden. Foruten de konkrete bygninger, senger etc. på Frilandsmuseet består kildematerialet av erindringer, folkelivsskildringer, reiseberetninger, Bibelen og moralske skrifter.

I innledningskapitlet, om søvnens kulturhistorie, settes det hele inn i en overordnet ramme. Forfatteren tar primært utgangspunkt i to retninger innenfor historieforskningen: mentalitetshistorien og kulturhistorien. Gjennom disse innfallsvinklene dokumenteres det hele veien at søvnen har forandret seg gjennom tidene. Tradisjonelt har man ment at folk sov mer før i tiden, men forfatteren viser til folkelivsskildringer som antyder at man ikke la seg noe særlig tidligere før enn nå. Oppfatningene om hva søvn betydde og hvilken rolle søvnen inntok i døgnrytmen, har imidlertid variert i stor grad. Ideen om at døgnet er omtrent likt fordelt mellom søvn, arbeid og hvile er en nymotens forestilling med røtter i industrialiseringens nye tidsforståelse fra slutten av 1800-tallet. Bondekulturens forestillinger om søvn var annerledes. Natten var svart som Satan og tilhørte åndene, som ofte kom på besøk i drømmene. De mørke timer ble tilbrakt halvt sittende, sammen med minst en annen person i dobbeltseng. Den sittende sovestillingen var alminnelig i Europa fra 1300-tallet til midten av 1800tallet. Grunnen til at det var minst to i hver seng var dels plassmangel, og dels fordi det ga en varmegevinst $i$ de kalde husene om vinteren. Boligene hadde lave tak og høye terskler, små vinduer og bare få rom et eget soverom ville vært helt utenkelig i disse boligene, som var innrettet for i størst mulig grad å unngå varmetap. I et samfunn som hadde andre grensedragninger inn mot det private, var det også helt naturlig å sove flere sammen. I sengen sov man naken - å skulle bruke dyrebare tekstiler om natten da man likevel sov, var helt utelukket. Alt dette endret seg i forbindelse med industrialiseringen. Søvnen ble privat - og skulle finne sted i dertil egnede rom. Enkeltsengene ble vanlig mot slutten av 1800-tallet, nå ble det ansett som uhygienisk å sove flere sammen, for ikke å snakke om hvor både uhygienisk og umoralsk det var å tilbringe natten naken. I en tid da man var opptatt av at barna måtte holde hendene over dynen for å unngå den farlige masturbasjonen, ble nattøyet vanlig også på landet - 100 år etter at det hadde slått gjennom hos eliten i tiden rundt den franske revolusjon. Pyjamasen ble hentet fra India av britene på 1800-tallet og kom raskt på moten.

Boken er rikholdig illustrert med mange fine bilder fra gårdene på Fyn og er godt skrevet og lettlest. Det teoretiske perspektivet med søkelys på hverdagslivet gjør at det til tider trekkes inn litt vel mange aspekter som ikke alltid er åpenbart forbundet med søvn. Den kan anbefales for alle som beskjeftiger seg med søvn på en eller annen måte - og det gjelder vel i grunnen oss alle.

\section{Anne Kveim Lie}

Institutt for allmenn- og samfunnsmedisin Universitetet i Oslo

\section{Spørsmålene som ikke ble stilt}

Wilmar B, Bruusgaard P. Frich JC et al, red. Penger og verdier $\mathrm{i}$ helsetjenesten

260 s, tab, ill. Oslo: Gyldendal Akademisk, 2009. Pris NOK 375

ISBN 978-82-05-39332-5

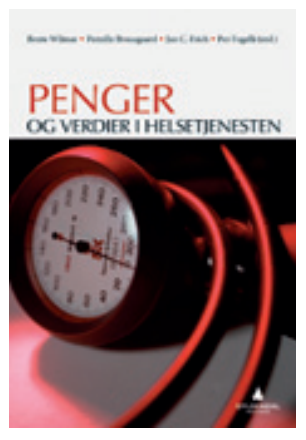

På vaskeseddelen står det: «Av og til kan pengenes makt true verdier vi i Norge vil skal prege helsetjenesten. ... Dette retter boken søkelys mot.» Forhåndsomtalen ga meg forventninger. Det er mange vanskelige spørsmål jeg gjerne skulle sett belyst, f.eks: Hvor stor er den reelle veksten i forbruket til helseformål hvis man korrigerer for antallet administrativt ansatte og for de administrative oppgavene som pålegges utøvende helsepersonell? Er det virkelig sant at etterspørselen etter helsetjenester er umettelig? Hvorfor er prioriteringsdebatten begrenset til å veie helsetiltak opp mot hverandre, og hvorfor får vi ingen diskusjon om prioritering av helseformål mot andre offentlige utgiftsposter? Hvordan kan det ha seg at de fleste sykehus bruker systemet med diagnoserelaterte grupper (DRG) til å evaluere avdelingers og seksjoners effektivitet, samtidig som DRG-ideologene i Helsedirektoratet bedyrer at systemet aldri var ment til dette?

Det kan tenkes at mine forventninger var for høye, og at det var derfor jeg ble litt skuffet. Boken består av 15 individuelle kapitler innrammet av en innledning og en avslutning forfattet av redaktørene. Og visst er her gode enkeltbidrag. Høydepunktet er Bjarne Jensens kapittel «Helseforetakene offentlig tjenesteproduksjon eller forretning?». For en novise i økonomifaget var det en fornøyelse å lese en fagøkonom som så forståelig avkler foretaksreformen dens retorikk. Olaug S. Lians bidrag om medisinen som det falske marked fikk også gjenkjennende nikk. Jan C. Frich og Lene Gjelseth Dalbak har skrevet hvert sitt leseverdige kapittel som med kasuistiske eksempler viser hvordan en overfokusering på finansieringsordninger kan korrumpere fagligheten i henholdsvis spesialist- og 
allmennhelsetjenesten. Men de nøyer seg med å beskrive; hvor er analysen av hvordan det er blitt slik, hvorfor vi som profesjonelle utøvere tillater det, og hva som er aktuelle mottrekk? Steinar Westins kapittel om bedriftsøkonomisk nytale har sine fornøyelige partier, men det er nok en ubevisst morsomhet når det $\mathrm{i}$ flere etterfølgende kapitler stadig benyttes det for tiden mest brukte nytale-ordet av dem alle, nemlig «samhandling».

Bokens svakhet er at forfatterne i for stor grad begrenser seg til å stille gårsdagens spørsmål. Ikke at ikke disse fortsatt kan være aktuelle; det er bare at de er temmelig utførlig beskrevet allerede. Vi visste vel fra før at farmasøytisk industri i for stor grad setter premissene for medisinsk forskning, at primærhelsetjenesten bør prioriteres, at norsk allmennmedisin forgubbes, at sykehusene ofte arbeider for fragmentert, og at det er altfor dårlig tilgang til legemidler i fattige land? Det ville vært mer spennende om man hadde stilt de spørsmålene som virkelig er blitt brennende de siste årene: Hvordan tøyle den farmasøytiske industriens påvirkningskraft uten å gjøre formalitetene rundt forskningen så ugjennomtrengelige at det blir enda vanskeligere å sjøsette et prosjekt uten et firma i ryggen? Hvordan unngå strategisk DRG-koding uten å engasjere selveste Riksrevisjonen? Hvordan få sykehusene mer funksjonelle uten å slå dem sammen til monstrøse organisatoriske enheter som vil sluke enda større administrative ressurser?

Forfatterne har nok stilt noen viktige spørsmål. Men de forspilte sin sjanse til å stille de viktigste.

Torgeir Bruun Wyller

Geriatrisk avdeling

Oslo universitetssykehus, Ullevål

\section{Økonomene kommer}

Haug K, Kaarbøe OM, Olsen TE, red.

Et helsevesen uten grenser?

363 s, tab, ill. Oslo: Cappelen Damm, 2009

Pris NOK 499

ISBN 978-82-02-30716-5

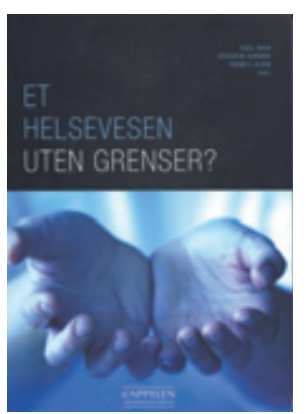

De 15 kapitlene er i første rekke skrevet av (helse)økonomer Tre leger har også bidratt, Kjell Haug (f. 1948), Stener Kvinnsland (f. 1948) og Stein A. Evensen (f. 1942). Evensens kapittelover-

skrift (kap. 3) er også blitt bokens tittel. Jeg synes ikke det har vært heldig. Det gir inn- trykk av at boken er normativ og debattorientert. Evensens og Kvinnslands kapitler er det, i noen grad også Haugs. Kvinnslands kapittel (kap. 2) har overskriften «Å velge betyr også å velge bort», mens Haugs (kap. 1) har «Verdens beste helsevesen?» De fleste av de øvrige kapitlene er nok i mange tilfeller også normative, men de er det på en faglig-teknisk måte. Deres forfattere viser, både prinsipielt og gjennom eksempler, hvilket potensial økonomisk teori og økonomiske analysemetoder har for å kaste lys over hvordan helsevesenet fungerer, hvorfor det fungerer som det gjør og hvordan det, gitt noen normative premisser, kan bringes til å fungere bedre.

Helseøkonomikken som forskningsdisiplin har vokst frem, til dels parallelt med, og som en del av helsetjenesteforskningen, siden 1970-årene. Denne boken viser at miljøet har nådd langt på en drøy generasjon. Det er i ferd med å utvikle kunnskap som kan brukes til å fagliggjøre også meget av ressursstyringen av helsevesenet, og dermed av den enkelte leges praksis. «Før» besto styringen og ledelsen i nokså stor grad i at medisinsk faglighet ble kombinert med legmannsskjønn. Skjønnet ble i betydelig grad utøvet av leger, men hva de mest overordnede beslutninger angikk, også av politikere og andre legfolk. Boken viser at økonomene har fått meget å tilby skjønnsutøverne, så meget at det kan komme til å gjøre dem svært avhengige av ekspertene. Det gjelder både de der «oppe», politikerne, og de der «nede», legene.

Økonomene kan selvsagt spesielt gi råd hva angår spørsmål om effektivitet av ulike slag. Men kan de også gi råd hva angår det normative? Ja, de kan det, for som anvendt orienterte forskere må de ta utgangspunkt i verdier eller normer. Mange av denne bokens forfattere gjør eksplisitt det. De tar særlig utgangspunkt i tre sett av verdier eller normer, (lidelsens) alvorlighet, rettferdighet (likhet av ulike slag) og (samfunns)nytte, altså det vi kunne kalle venstreliberale (sosialdemokratiske) verdier. Dette er de verdier og normer som dominerer innen helsepolitikken. Verken politikere eller leger har vært presise med hensyn til hvordan de forstår disse verdier og hvordan de prioriterer dem. Helseøkonomene må være det skal de komme noen vei. Det er ikke politikere og leger som har utviklet begrepet om kvalitetsjusterte leveår; det er økonomer. Dermed er økonomene med på om ikke å skape verdiene, så på å konkretisere dem og dermed langt på vei å «styre» prioriteringen av dem.

Utviklingen av denne helseøkonomiske, og mer allment, denne styrings- og ledelsesvitenskapelige, kunnskap kan ses i sammenheng med utviklingen av den kunnskapsbaserte medisin. Mens den kunnskapsbaserte medisin vitenskapeliggjør «resten» av den rent medisinske skjønnsutøvelse, vil den kunnskapsbaserte helse- politikk og helseledelse vitenskapeliggjøre den ledelsesmessige, eller ressursmessige, skjønnsutøvelse legen tidligere kunne foreta. De to faglige «bevegelser» representerer slik et dobbelt, og i prinsippet fullstendig, angrep på legens skjønnsutøvelse som kliniker. Legen må, det er ikke minst denne bokens implikasjon, underkaste seg både kliniske og økonomiske retningslinjer. En medisinsk beslutning er jo aldri bare medisinsk, den er også økonomisk. Den gjelder pasientens helse, men den gjelder også, alltid, ressursbruk.

Jeg har satt perspektivene på spissen, men mange av kapitlene viser at utviklingen går raskt, i den retningen jeg her har antydet. De viser også hvor normativt ivrige mange samfunnsforskere er blitt. De studerer helsevesenets måte å virke på, men de gjør det i stor grad for å påvirke det, altså for å bidra til å fagliggjøre styringen av det. Paradoksalt nok blir de slik også en slags ideologiske aktører. De er med på å skape den virkelighet (empiri) de selv, eller deres etterfølgere, i neste omgang skal studere (og påvirke). De fleste av forfatterne representerer et bestemt sett av styringsteorier, de økonomiske. Det er også disse som i praksis dominerer, men av kapitlet til Kari Nyland \& Katarina Østergren (kap. 11) fremgår det at det er konkurrerende styringsteorier og at forholdet mellom dem endrer seg. De viser gjennom sin studie av sykehusstyrer at sykehusreformen var preget av et økonomisk styringsperspektiv, men at dette etter 2005 ble modifisert av legmannsperspektivet (politisering av styrene). Nå er også, peker de på, et annet teoriinspirert perspektiv på vei inn, nemlig nettverksperspektivet (samhandling).

Siden denne boken gir et innblikk i en tenkning leger i stigende grad vil bli rammet av, bør den være av interesse for dem. Noen kapitler bør være av særlig interesse. Erik Nord har skrevet pedagogisk godt om økonomisk evaluering av helsetiltak (kap. 6). Jan Erik Askildsen, Tor Helge Holmås \& Oddvar Kaarbøe (kap. 7) har på en elegant måte vist hvordan man med utgangspunkt i medisinske veiledere om hvem som skal ha rett til nødvendig helsehjelp og hva som er den lengste forsvarlige ventetid for pasientene, og data om faktisk ventetid, kan studere prioriteringspraksis i spesialisthelsetjenesten. Oddvar Kaarbøe (kap. 9) har påpekt at ordningen med rettighetspasienter (individuell frist) åpner opp for bruk av graderte egenandeler. Trond Bjørnenak, Kari Nyland \& Katarina Østergren (kap. 12) har drøftet hvordan kapitalomkostninger kan brukes som et verktøy for styring av og i helseforetak og finner at måten kapitalomkostningene i dag beregnes på, systematisk undervurderer de virkelige omkostninger.

De fleste kapitlene holder et høyt analytisk nivå. Noen, som sluttkapitlet (kap. 14) om helseforsikringens fremvekst og rolle 